\title{
Second Annual North American Labor History Conference
}

\section{Michael Hanagan}

Vanderbilt University

The Second Annual North American Labor History Conference was held at Wayne State University, October 9-11, 1980. The Department of History of Wayne State University and the Walter P. Reuther Library of Urban and Labor Affairs sponsored the conference. The opening address was by Crystal Lee Sutton. "The Real Struggle in the South by the Real Norma Rae," personal reflections on life in the Southern cotton mills and an explanation of the significance of the J.P. Stevens boycott. Most of the sessions focused on North American labor: the IWW in Canada and the United States and the rise of industrial unionism were principal themes. Several sessions provided a comparative European labor context. Sessions were held on the following topics: "Community and Union in Two Tobacco Towns: Case Studies in Industrial Unionism, 1930-1950," "Radical Unionism in the Canadian West, 1900-1930," “The IWW on Film," "Industrial Unionism in Song. " "Industrial Unionism and Protest in Two Nations," "The Rise of the CIO," and "Anglo-American Industrial Unionism." Workers" Education League 189 (formerly AFT) organized a tour of the scenes of labor struggles in Detroit during the twenties and thirties.

The conference was well attended by scholars and labor activists. Many weil-known labor militants who contributed to the building of the $\mathrm{CIO}$ in Detroit shared in the discussions. 